\title{
A Review of Literature on the Use of Clickers in the Business and Management Discipline
}

\author{
Nripendra P. Rana \\ School of Management, Swansea University, \\ Swansea, SA2 8PP, Wales, UK \\ nrananp@gmail.com \\ Yogesh K. Dwivedi ${ }^{1}$ \\ School of Management, Swansea University, UK \\ ykdwivedi@gmail.com \\ Wassan A.A. Al-Khowaiter \\ Department of MIS and PM, Qassim University, Saudi Arabia \\ w.alkhowaiter@gmail.com
}

\begin{abstract}
Classroom response systems (clickers), in their various forms, are widely used across disciplines, demonstrating effectiveness across a range of different educational settings. However, only a few literature reviews on this technology have been undertaken in general, and no review has yet been performed on this topic in the business and management context. Realising the existing research gap, this article reviews 33 clicker-related studies from the business and management discipline that are largely focused on student perceptions and outcomes. The purpose of this paper is to provide a critical and balanced review of articles from the business and management discipline on various themes such as learner's engagement, performance, learning, participation, satisfaction, feedback, attendance, enjoyability, motivation, and interactivity, to name a few. The review also provides a brief account of lessons learned from the literature published in other disciplines and recommendations provided by studies from the business and management discipline.
\end{abstract}

Keywords: Review, Clickers, Business, Management, Lessons, Recommendations

\section{Introduction}

Information technology (IT) has been recently considered as a strategic resource in educational settings, providing educational institutions with a distinctive opportunity to enhance student motivation and improve learning outcomes (Blasco-Arcas et al., 2013; Roblyer and Wiencke, 2003). To continue to maintain class interest, focus, and motivation, today's students expect more visually motivating material and integration of technology into

${ }^{1}$ Corresponding Author: Professor Yogesh K. Dwivedi, Personal Chair and Director of Research, School of Management, Swansea University, Bay Campus, Fabian Way, Swansea, Wales, SA1 8EN, Phone: + 44 (0)1792 602340; Email: y.k.dwivedi@swansea.ac.uk; ykdwivedi@gmail.com 
their lessons (Smart et al., 1999). Studies have demonstrated that active involvement can bring in-depth understanding and greater knowledge retention while motivating higher intellectual processes and critical thinking skills (Conrad and Donaldson, 2004; Mareno et al., 2010). Therefore, mastering the art of engaging students in the learning is indispensable to successful learning outcomes. Clickers, also known as classroom response system (CRS), audience response system (ARS), personal response system (PRS), group response system (GRS), or student response system (SRS), are broadly used across university courses for a number of reasons but largely for creating an active learning environment (Bruff, 2009; Carnaghan and Webb, 2007).

The use of clickers in the classroom has gained popularity in the academic environment over the past few years (Bonaiuti et al., 2015; Carnaghan and Webb, 2007; Hatziapostolou et al., 2014; Lai et al., 2015; Lojo, 2009; Mula and Kavanagh, 2009). Most of the early clicker research has been undertaken in the context of the health/medical professions and natural sciences as these disciplines were the early adopters of clicker technology. However, studies on clicker use have started to appear in a number of other academic disciplines. The increasing interest in clicker technology by the researchers is largely due to the services provided by clicker usage including instant and anonymous feedback of student understanding (Barnett, 2006; Crossgrove and Curran, 2008; Gagne, 2011; Lincoln, 2008; MacArthur and Jones, 2008), improvements in student performance (Caldwell, 2007; Ueltschy, 2001), attendance (Caldwell, 2007; Koenig, 2010; Lincoln, 2008), attention (Crossgrove and Curran, 2008; Lincoln, 2008; Prather and Brissenden, 2009), and participation (Addison et al., 2009; Salemi, 2009; Sprague and Dahl, 2010). However, clickers are not beyond certain drawbacks, including difficulty in designing effective clicker questions related to critical thinking, which are focused on synthesis, evaluation, and analysis (Herreid, 2006), cost (Barnett, 2006; Blasco-Arcas et al., 2013; Herreid, 2006; Kay and LeSage, 2009; Strasser, 2010), technical glitches in the devices (i.e., inoperable clickers) (Barnett, 2006; Blasco-Arcas et al., 2013; Herreid, 2006; Kay and LeSage, 2009; Koenig, 2009), additional preparation time required by the instructor (Koenig, 2009), interrupted flow of lectures (Koenig, 2009; Strasser, 2010), etc.

The benefits (such as immediate feedback, improved interaction with the instructor, supporting anonymity for critical and sensitive questions) and certain barriers or challenges (such as cost, clicker-enabled course material preparation time, encouraging only implicit participation) provided by clickers in the classroom learning environments have been documented for some disciplines (e.g., nursing, medical, pharmacy, paramedical, etc.). However, acceptance and use of clickers in other disciplines, particularly in business and management, has not been much considered in the literature yet (Keough, 2012). Therefore, this study provides a review of existing literature on clicker use from the business and management perspective and synthesises findings to understand the overall knowledge in this area.

\section{What are clickers? Key advantages and disadvantages}


Clickers are small receivers that look similar to a television remote control. They are sophisticated technological devices that allow students to rapidly answer questions in the class. An infrared or radio frequency receiver and software on the instructor's computer captures students' responses. The computer software records responses and collates them into a database. Students are presented with a question through a PowerPoint slide, with a range of answers, which are designated with a number or letter. Respondents then key the number or letter correlating to their answer, which through the receiver is composed and then organised. Response can be anonymous or linked to specific students through the clickers' unique IDs, allowing the instructor to know students' responses to analyze their attendance or to know who gave correct or incorrect responses (Blasco-Arcas et al., 2013; Mula and Kavanagh, 2009; Stagg and Lane, 2010). They are also known in their different forms including ARS (Guthrie and Carlin, 2004), CRS (Nelson and Hauck, 2008), Electronic Response System (ERS) (Robinsson, 2007), GRS (Carnaghan and Webb, 2007), PRS (Humphries and Whelan, 2009; Matestic and Adams, 2008), and SRS (Bain and Przybyla, 2009) across different studies.

The literature suggests that clickers deliver significant advantages to both instructors and students (Bergtrom, 2006; Blasco-Arcas et al., 2013; Bullock et al., 2002; Simpson and Oliver, 2007). They provide instructors with immediate feedback on students' responses. They are useful to students in terms of improving their engagement, participation, performance, learning, satisfaction, motivation, understanding, interaction, etc. in the class (Blasco-Arcas et al., 2013; Caldwell, 2007). Despite these benefits of clickers, some disadvantages should also be noted. Although the cost of this technology has reduced in recent years, it is still significantly high for some educational institutions. This well may be a barrier for some educational institutions to adopting and integrating them in their learning process. Also, due to their occasional technical glitches, bugs, and failures, they may be annoying and unsatisfying to use at times (Blasco-Arcas et al., 2013; Kay and LeSage, 2009). Further, the instructor needs to devote a lot of time to designing clicker quizzes. These are not only difficult to compose but also need to be designed in a way that can really test students' understanding on the related subject matter (Strasser, 2010). Clickers were also criticised for interrupting the flow of the lecture and taking up a greater amount of class time (Koenig, 2009; Strasser, 2010). Herreid (2006) argued that clickers are specifically efficient for deriving responses to questions at the lower levels of Bloom's (1956) taxonomy, where questions concerning facts such as remembering and understanding are involved. However, when it comes to the highest level of Bloom's (1956) taxonomy (i.e., questions related to critical thinking, which is focused more on synthesis, evaluation, and analysis), designing effective questions needs significant creativity and time.

\section{Research methodology}

We employed a systematic review to classify, gather, and analyze relevant literature on clicker technology using keywords such as clickers, turning point, audience response system, personal response system, and classroom response system in 29 appropriate and related journals on education [see Appendix [A] for the list of journals]. However, we could get access to only eight articles (out of a total of 72 articles from all disciplines) on various 
streams of business and management including accounting, marketing, finance, business statistics, operations management, industrial management, and management information systems. Realising the number to be relatively few, we intended to search for the relevant articles from Google Scholar using phrases such as clickers in ("business", "management", "accounting", "finance", "management information systems", and "marketing") every time with a quoted keyword. Using this approach, we found 25 articles on the use of clickers in various streams of business and management from outlets other than the journals mentioned in Appendix [A]. As a result, this research obtained a collection of 33 articles to present the literature review.

\section{Literature review}

The review of literature on the use of clickers in the various streams of business and management revealed that only 33 articles have been published in this area to date. These articles comprise 14 from business (e.g., Blasco-Arcas et al., 2013; Heaslip et al., 2014; Thoms and Williams, 2010), eight from accounting (e.g., Carnaghan et al., 2011; Chui et al., 2013; Dunnett et al., 2011), six from management (e.g., Han and Finkelstein, 2013; Kullven and Westin, 2012), four from marketing (e.g., Hedgcock and Rouwenhorst, 2014; Sprague and Dahl, 2010), two from management information systems (MIS) (i.e., Bain and Przybyla, 2009; Hoanca, 2009), and one from finance (i.e., Snavely and Chan, 2008) (see Table 1). Moreover, two articles (i.e., Humphries and Whelan, 2009; Robinsson, 2007) were used in cross-discipline streams of business and management. For example, Humphries and Whelan (2009) used both business and accounting streams whereas Robinsson (2007) used accounting and marketing streams.

Table 1. Specific streams of clicker-based studies (Source: Adapted from Keough (2012))

\begin{tabular}{|l|l|}
\hline Stream (No. of Articles) & Supporting Source(s) \\
\hline \multirow{3}{*}{ Business (14) } & $\begin{array}{l}\text { Blasco-Arcas et al. (2013), Buyukkurt et al. (2012), Eastman et al. } \\
(2011), \text { Fryling (2013), Guthrie and Carlin (2004), Hancock }\end{array}$ \\
& $\begin{array}{l}\text { (2010), Heaslip et al. (2014), Humphries and Whelan (2009), } \\
\text { Jones (2011), Jones and George (2011), Koppel and Berenson } \\
(2008), \text { Matestic and Adams (2008), Stagg and Lane (2010), } \\
\text { Thoms and Williams (2010) }\end{array}$ \\
\hline Accounting (8) & $\begin{array}{l}\text { Carnaghan and Webb (2007), Carnaghan et al. (2011), Chui et al. } \\
(2013), \text { Dunnett et al. (2011), Humphries and Whelan (2009), } \\
\text { Marshall and Varnon (2012), Mula and Kavanagh (2009), } \\
\text { Robinsson (2007) }\end{array}$ \\
\hline Management (6) & $\begin{array}{l}\text { Han and Finkelstein (2013), Kullven and Westin (2012), Lojo } \\
(2009), \text { Nelson and Hauck (2008), Robinsson (2007), Slauson } \\
\text { (2011) }\end{array}$ \\
\hline Marketing (4) & $\begin{array}{l}\text { Hedgcock and Rouwenhorst (2014), Lincoln (2007), Robinson } \\
\text { and Ritzko (2006), Sprague and Dahl (2010) }\end{array}$ \\
\hline Management Information Systems (2) & Bain and Przybyla (2009), Hoanca (2009) \\
\hline Finance (1) & Snavely and Chan (2008) \\
\hline
\end{tabular}

To undertake the critical review of literature, we divided the studies primarily based on their possible themes into 17 various categories (see Table 2). The analysis indicates that engagement is the most explored aspect of clickers in the educational settings followed by performance, learning, participation, feedback, satisfaction, attitude, anonymity, attendance, 
motivation, fun to use or enjoyability, interactivity, assessment, understanding, effectiveness, and attention as some other frequently used themes.

Table 2. Clickers' themes (Source: Adapted from Keough (2012))

\begin{tabular}{|c|c|c|}
\hline Theme & Freq & Supporting Source(s) \\
\hline Engagement & 13 & $\begin{array}{l}\text { Blasco-Arcas et al. (2013), Carnaghan and Webb (2007), } \\
\text { Carnaghan et al. (2011), Fryling (2013), Han and Finkelstein } \\
\text { (2013), Heaslip et al. (2014), Jones (2011), Marshall and Varnon } \\
\text { (2012), Matestic and Adams (2008), Mula and Kavanagh (2009), } \\
\text { Robinsson (2007), Slauson (2011), Stagg and Lane (2010) }\end{array}$ \\
\hline Performance & 12 & $\begin{array}{l}\text { Bain and Przybyla (2009), Blasco-Arcas et al. (2013), Chui et al. } \\
\text { (2013), Dunnett et al. (2011), Hedgcock and Rouwenhorst (2014), } \\
\text { Hoanca (2013), Keough (2012), Lojo (2009), Marshall and Varnon } \\
\text { (2012), Mula and Kavanagh (2009), Nelson and Hauck (2008) }\end{array}$ \\
\hline Learning & 10 & $\begin{array}{l}\text { Carnaghan and Webb (2007), Carnaghan et al. (2011), Han and } \\
\text { Finkelstein (2013), Hedgcock and Rouwenhorst (2014), } \\
\text { Humphries and Whelan (2009), Koppel and Berenson (2008), } \\
\text { Kullven and Westin (2012), Nelson and Hauck (2008), Sprague } \\
\text { and Dahl (2010), Stagg and Lane (2010) }\end{array}$ \\
\hline Participation & 10 & $\begin{array}{l}\text { Bain and Przybyla (2009), Carnaghan and Webb (2007), Fryling } \\
\text { (2013), Guthrie and Carlin (2004), Heaslip et al. (2014), Jones } \\
\text { (2011), Keough (2012), Kullven and Westin (2012), Matestic and } \\
\text { Adams (2008), Thoms and Williams (2010) }\end{array}$ \\
\hline Feedback & 9 & $\begin{array}{l}\text { Han and Finkelstein (2013), Hedgcock and Rouwenhorst (2014), } \\
\text { Keough (2012), Koppel and Berenson (2008), Lincoln (2007), } \\
\text { Mula and Kavanagh (2009), Nelson and Hauck (2008), Stagg and } \\
\text { Lane (2010), Thoms and Williams (2010) }\end{array}$ \\
\hline Satisfaction & 7 & $\begin{array}{l}\text { Carnaghan and Webb (2007), Carnaghan et al. (2011), Eastman et } \\
\text { al. (2011), Keough (2012), Koppel and Berenson (2008), Kullven } \\
\text { and Westin (2012), Sprague and Dahl (2010) }\end{array}$ \\
\hline Attendance & 7 & $\begin{array}{l}\text { Bain and Przybyla (2009), Carnaghan et al. (2011), Dunnett et al. } \\
\text { (2011), Keough (2012), Kullven and Westin (2012), MacArthur } \\
\text { and Jones (2011), Nelson and Hauck (2008) }\end{array}$ \\
\hline Attitude & 6 & $\begin{array}{l}\text { Eastman et al. (2011), Hedgcock and Rouwenhorst (2014), Jones } \\
\text { (2011), Jones and George (2011), Kullven and Westin (2012), } \\
\text { Sprague and Dahl (2010) }\end{array}$ \\
\hline Fun to Use/Enjoyable & 6 & $\begin{array}{l}\text { Bain and Przybyla (2009), Carnaghan et al. (2011), Koppel and } \\
\text { Berenson (2008), Lincoln (2007), Robinsson (2007), Thoms and } \\
\text { Williams (2010) }\end{array}$ \\
\hline Anonymity & 5 & $\begin{array}{l}\text { Guthrie and Carlin (2004), Heaslip et al. (2014), Koppel and } \\
\text { Berenson (2008), Matestic and Adams (2008), Sprague and Dahl } \\
(2010)\end{array}$ \\
\hline Ease of Use & 5 & $\begin{array}{l}\text { Guthrie and Carlin (2004), Heaslip et al. (2014), Keough (2012), } \\
\text { Lincoln (2007), Matestic and Adams (2008) }\end{array}$ \\
\hline Motivation & 4 & $\begin{array}{l}\text { Jones (2011), Marshall and Varnon (2012), Nelson and Hauck } \\
\text { (2008), Thoms and Williams (2010) }\end{array}$ \\
\hline Interactivity & 4 & $\begin{array}{l}\text { Blasco-Arcas et al. (2013), Jones (2011), Slauson (2011), Thoms } \\
\text { and Williams (2010) }\end{array}$ \\
\hline Assessment/Setting the Grade & 4 & $\begin{array}{l}\text { Han and Finkelstein (2013), Hancock (2010), Kullven and Westin } \\
\text { (2012), Matestic and Adams (2008) }\end{array}$ \\
\hline Understanding & 4 & $\begin{array}{l}\text { Bain and Przybyla (2009), Fryling (2013), Hedgcock and } \\
\text { Rouwenhorst (2014), Jones (2011) }\end{array}$ \\
\hline Effectiveness & 3 & $\begin{array}{l}\text { Humphries and Whelan (2009), Lojo (2009), Snavely and Chan } \\
\text { (2008) }\end{array}$ \\
\hline Attention & 3 & $\begin{array}{l}\text { Buyukkurt et al. (2012), Keough (2012), Marshall and Varnon } \\
\text { (2012) }\end{array}$ \\
\hline
\end{tabular}


Moreover, the themes (not presented in Table 2) such as confidence, efficacy, and security have been discussed by only one study and hence are relatively under-represented. We will also discuss these under-represented themes separately. The following sub-sections will summarise the findings related to various themes.

\subsection{Student engagement, participation, and interactivity}

The largest 13 out of 33 studies from the business and management discipline highlighted the significance of student engagement using clickers. As engagement is determined by the interactions between the environment and individual (Finn and Rock, 1997), it is found to be closely associated with interactivity (explored in four studies with three common studies along engagement). Moreover, participation (explored in ten studies with four studies along engagement) could also be seen as one facet of student engagement (Carnaghan et al., 2011). Hence, it is worth reviewing participation and interactivity along engagement. For example, based on the proposed conceptual framework, Blasco-Arcas et al. (2013) found that the high level of student interactivity with peers and teacher is promoted by the use of clickers that positively influences their engagement. However, this study consisted only of students who have used clickers, and hence its results cannot be compared with a control group of nonusers. This comparison could have helped researchers to better understand not only the benefits but also the impacts that the barriers to adopting this technology would have on student learning performance.

Contrary to their predictions, Carnaghan and Webb (2007) found a moderately significant decline in student engagement when a GRS was used. The authors found that participation actually decreased, particularly when most students answered the questions correctly. Carnaghan et al. (2011) found some possible factors which positively increased student participation and engagement. These include interspersing and sufficiently difficult SRS questions, instructor flexibility in exploring issues when SRS aggregated response indicates low understanding of the topic, and displaying the aggregated response graph. The summary of findings clearly indicates that the better correlation between student participation and engagement is not necessarily accomplished due only to this automated technology.

In answer to a question of whether only clickers increase student engagement and participation, Fryling (2013) uncovered that clickers and participation tickets (an additional reward mechanism offered to students who spoke up to answer a question, posed a question, or simply participated in some discourse rather than just silently clicking the device to implicitly participate in the class discussion as encouraged by clickers) were broadly accepted and valued by students in all classes. As the responses provided by clickers were kept completely anonymous or only known to the instructor, the clicker alone did not encourage student participation. The shy students did not intend to take part in any discussion. Hence, the author found participation tickets to be a true medium to enhance students' engagement through their explicit participation in discourse and class discussions (Fryling, 2013). Similarly, finding ways to increase interactivity, Slauson (2011) reported that students remain more engaged with courses when clickers are used along with the easy Excel tools. However, 
the authenticity of the use of the additional tools toward enhancing interactivity and engagement was checked for only two courses of 25 students each.

Jones (2011) explored how the clickers influence the native vs. immigrant students' involvement, interaction, and participation in the classroom in the US. The findings indicated that native-born US students believed more positively toward these factors while using the technology than the corresponding immigrant students. The author argued that this could partly be due to the role that technology would have played in the native-born students' lives. The majority of the native-born students would have used the technology since their childhood and such connectivity diffused into their lives. However, much of the connectivity these students have with such technology is largely for entertainment purposes, and they might see the classroom as yet another stage for entertainment. This could possibly undermine the overall purpose of clickers in classroom settings, and native-born students may consider them just another tool merely for the purpose of entertainment and fun. The immigrant students, however, held relatively lower attitudes toward the technology. This might be because they had not had as much exposure to technology right from their youth, coupled with their intense focus on the traditional attitudes to education and learning as taught by their parents. Han and Finkelstein (2013) uncovered that professors' clicker assessment and development has a positive impact on student perceptions of their engagement.

Some other studies (e.g., Heaslip et al., 2014; Marshall and Varnon, 2012; Matestic and Adams, 2008; Mula and Kavanagh, 2009; Robinsson, 2007; Stagg and Lane, 2010) indicated that use of clickers increased student engagement in the class. For example, Heaslip et al. (2014) established that students became more engaged when clickers were in use in the lecture room than when they were not. The findings also suggested that students appreciate the anonymity afforded by clickers while responding to the lecturer's questions in class. However, the result again questions the overall usefulness of the technology, as it does not help in promoting students' open discussion and detailed deliberations on the subject matter. Marshall and Varnon (2012) also obtained similar findings, which indicated that integrating formal questions through PowerPoint slides probably creates students' engagement more than the professor simply posing questions out loud in class.

Similar to the results of the earlier studies, Matestic and Adams (2008) also established that enhanced student engagement was a direct outcome of using clickers in the class. Mula and Kavanagh (2009) provided the initial manifestation of the efficacy of clickers in enhancing student engagement. However, as this result is based on the use of clickers in one semester only, a relatively long time period is needed to fully evaluate the impact of clickers in teaching and learning. Based on student response, Robinsson (2009) reported that the use of clickers enhanced student engagement with the class. However, this study warrants further investigation on how both men and women reap benefit from the use of clickers in the classroom. Based on student survey, Stagg and Lane (2010) also found that the use of clickers helped students to actively engage in the class. 
According to the responses of management and marketing students on clicker usage, Thoms and Williams (2010) found that the instructor enjoyed the interaction and a large majority of students (i.e., 85\%) agreed that they were comfortable in participating in the course, as no one knew how they responded to the instructor's questions. However, such results pose questions regarding the use of clickers as it is merely used as a technology to promote implicit participation and hypothetical interaction. Accomplishing such objectives with clickers can only work for small class teaching with some straightforward questions. Such findings may not work properly for the large class with greater deliberations required to reach any conclusion. Moreover, a few studies also answer the questions related to the use of clickers particularly in connection with student participation (i.e., Bain and Przybyla, 2009; Guthrie and Carlin, 2004; Keough, 2012; Kullven and Westin, 2012; Thoms and Williams, 2010). For example, Bain and Przybyla (2009) in an MIS context, Guthrie and Carlin (2004) in the context of business, and Keough (2012) and Kullen and Westin (2012) in the context of management report a positive level of participation experienced by students with clickers. However, Bain and Przybyla (2009) note that many other students (i.e., 49\%) do not think that clickers encourage them to take notes in class and let them participate in discussions.

\subsection{Student performance}

Clickers can be used to measure student performance in one form or the other. Twelve studies (see Table 2) have examined the student perceptions of performance as an outcome of clicker use. The review provided mixed results where the majority of studies (i.e., Bain and Przybyla, 2009; Hedgcock and Rouwenhorst, 2014; Hoanca, 2013; Keough, 2012; Nelson and Hauck, 2008) advocated the use of clickers as they enhanced student performance in some form. However, other studies found that there was either no significant difference in terms of student overall course performance when clickers were used (i.e., Chui et al., 2013; Dunnett et al. 2011; Lojo, 2009) or that clickers alone are not able to enhance student performance (i.e., Blasco-Arcas et al., 2013).

Chui et al. (2013) found that students using clickers performed better in in-class quizzes; however, they reported that their overall course performance did not differ based on whether clickers were made available to students during the semester. Moreover, the use of clickers integrated with peer instructions significantly influenced students' performance in the class settings. For example, Dunnett et al. (2011) found enhanced performance by students in a "mixed" class where one half of them used clickers and the other half did not whereas Lojo (2009) demonstrated that use of clickers had a statistically significant impact on open-ended exam questions, but no measurable influence on multiple-choice qualitative questions. Based on their findings from the empirical quantitative research, Blasco-Arcas et al. (2013) highlighted that learning performance may be derived not only exclusively from the use of clicker technology but also from the development of peer group practices. On similar lines, Marshall and Varnon (2012) also found that the use of clickers alone does not enhance performance. However, the combination of clickers and peer instructions improves students' performance. Clickers can be considered an equally useful tool for instructors to understand what proportion of the overall students in the class are not participating willingly in the discussion. The trend of such students who are constantly hesitant in using clickers can be 
analyzed, and they can be given some additional tutorials to keep up with those students who take the initiative in making the discussion lively and vibrant in the classroom environment.

Furthermore, Mula and Kavanagh (2009) found the evidence inconclusive as far as the effect of the use of clickers on student performance is concerned. This clearly indicates that the use of clickers does not always lead to increased student performance. It rather depends on many other factors such as discussion with peers, motivation from instructors, etc. Bain and Przybyla (2009) compared student performance for those who used clickers to the non-users in the MIS class and found that their performance significantly increased during the semester. Keough (2012) also performed a similar analysis for users vs. non-users of clickers and found a significant difference between their performances. Hoanca (2013) in the context of MIS found that the clickers score was simply correlated with student overall performance. However, Blasco-Arcas et al. (2013) highlighted that student learning performance is derived not only from technology but also from the development of peer group practices.

\subsection{Students' improved understanding and learning}

Given the benefits that clickers provide to the students for better class participation, improved engagement, increased interactivity, etc., ten studies (see Table 2) explore student perceptions toward their learning, and there are four on content understanding experiences. As understanding the course content can be considered as an overall part of the student learning process (see Han and Finkelstein, 2013), it is worth reviewing these two themes together. For example, Carnaghan and Webb (2007) and Carnaghan et al. (2011) in the context of accounting classes found that use of clickers resulted in modest improvements in learning on average, although certain student groups may benefit more. Carnaghan and Webb (2007) also note that the learning improvements were more likely to occur for those exam questions similar in style to the ones covered with the SRS. Han and Finkelstein (2013) in the context of management higher education found that students perceive the use of clickers as having an impact on their learning. The study further suggests that clicker assessment and feedback (CAF) is the most effective mechanism for student learning when it is supported by relevant CAF development of professors and their formative use of CAF during teaching. Hedgcock and Rouwenhorst (2014) showed that students reported a better understanding of the material and their abilities to measure their own learning when clickers were used for feedback purposes.

Similar findings were obtained by Kullven and Westin (2012) in the context of management, Nelson and Hauck (2008) for MIS, Sprague and Dahl (2010) for marketing, and Stagg and Lane (2010) for business where authors highlighted the use of clickers to facilitate student learning. Humphries and Whelan (2009) also supported the use of a PRS and found that it enhances perceived student learning. However, the objective measures of student learning (i.e., exam results) did not demonstrate the predicted improvement about the effectiveness of a PRS. Stagg and Lane (2010) prescribed students to practically engage in applying the skills learned and to use these basic principles as a basis of in-depth learning, whereas Sprague and Dahl (2010) observed that students with a low need for cognition or facing cultural barriers were shown to have a better learning experience when using clicker technology. The authors 
also supported the philosophy where they solicited future researchers to integrate other appropriate classroom technologies to facilitate a better student learning experience.

Moreover, although Koppel and Berenson (2008) accepted the use of an SRS as a way of engaging students in the learning process, they argued that using clickers is by no means a panacea. In other words, clickers cannot be a replacement for a well-prepared, motivated, and dynamic instructor. Studies such as Bain and Przybyla (2009), Fryling (2013), and Jones (2011) supported the notion that there is better comprehension or understanding of the course material using clickers. However, as Fryling's (2013) research is exploratory in nature, it emphasised the need for further enquiry into the additional tools to be used along with the clickers, which enhance the understanding of the course content. In addition to the prior findings, Bain and Przybyla (2009) also found that discussing the questions with their classmates helps students in understanding the course material.

\subsection{Assessment and feedback}

The findings of the literature supported the capability of clickers as a tool for assessment and feedback (see Table 2). Nine studies examined feedback whereas four explored assessment. Han and Finkelstein (2013) considered clickers as a tool for both instructional assessment and feedback and found the positive impact of these strategies on student engagement and learning. The other studies, such as Hedgcock and Rouwenhorst (2014) and Lincoln (2007) in the context of marketing, Keough (2012) as a literature review, Koppel and Berenson (2008), Stagg and Lane (2010), and Thoms and Williams (2010) from business studies, Mula and Kavanagh (2009) from accounting, and Nelson and Hauck (2008) from MIS, have supported the use of clickers for providing a high level of timely feedback to students, which leads to improved student learning outcomes. For example, Stagg and Lane (2010) revealed that the use of clicker technology not only allows students to get instant feedback on the course content but also allows instructors to provide immediate feedback to students. Han and Finkelstein (2010) concluded that when using CAF in the classroom, the formative feedback with CAF has more influence than summative feedback on students' perceptions. Further, Lincoln (2007) found that although the majority of students liked clickers for their ability to provide instant feedback to them, a smaller percentage of students (i.e., almost one-fifth of the overall sample) also said "no" to this for quiz feedback. It was argued that those students who did not do well in the quizzes would probably consider this as a waste of time (Lincoln, 2007).

Although some studies (e.g., Thoms and Williams, 2010) have outlined that both students and instructors reap the benefits of the clickers' feedback, none of them have emphasised the discussions of how student feedback can help instructors to change their strategy of teaching in the absence of adequate evidence of understanding through the feedback system. Also, these studies remain largely silent on how such strategy can effectively provide individual feedback to students in the context of tests or quizzes. Moreover, studies like Hancock (2010), Kullven and Westin (2012), and Matestic and Adams (2008) have supported summative and formative assessment using clickers. However, none of the studies have 
provided detailed information on how the clickers can act as a substitute for the formal examination as a part of summative assessment.

\subsection{Student satisfaction and enjoyment}

Studies generally find that clicker use either results in more student satisfaction or greater enjoyment of the courses (Carnaghan et al., 2011). The literature review indicates that only seven studies have explored student satisfaction and six analyzed enjoyment. For example, Carnaghan and Webb (2007) and Carnaghan et al. (2011) in the accounting context, Eastman et al. (2011) and Koppel and Berenson (2008) in the business context, Keough (2012) and Kullven and Westin (2012) in the management context, and Sprague and Dahl (2010) in the marketing context report the improvement of student satisfaction with the use of clickers in the classroom. However, Carnaghan and Webb (2007) found limited evidence of clickers in course satisfaction whereas Carnaghan et al.'s (2011) results only showed preliminary evidence regarding the effects of an SRS on student satisfaction. Carnaghan et al. (2011) also note that a small minority of students did not like the SRS as far as improved student satisfaction and enjoyment are concerned.

Analyzing the survey response of six questions on enjoyment, Bain and Przybyla (2009) found that most students enjoyed using the clickers. However, certain percentages (i.e., 2\%$17 \%$ ) of students were not in agreement concerning those questions. Koppel and Berenson (2008) asked a couple of questions to four different sections of a class on student enjoyment. The findings indicated a mixed outcome where the mean of response of one section of students was not found favorable in comparison to others. Also, Lincoln (2007) in the context of a marketing class found that clickers made the class enjoyable for the majority of students. However, about $37 \%$ students also did not agree with this. Based on the students' comments, Robinsson (2007) asserts that the students enjoyed using clickers in the class and considered it fun. Thoms and Williams (2010) also report similar results for both instructor and students.

\subsection{Attitudes of students and faculties}

Research suggests that for clickers to be successful, the instructor's focus should be on students' attitude toward use and accepting the technology rather than the technology itself (MacArthur and Jones, 2008). Only six studies emphasised students' attitude toward using clickers. For example, Eastman et al. (2011) measured students' attitude with the use of interactive technology and found it fairly high. Hedgcock and Rouwenhorst (2014) asked six questions to measure attitude toward clicker use. The majority of students responded negatively to a couple of questions related to their choice where the class would not have clickers and bringing clickers to the class is inconvenient.

Analyzing the attitude of native-born and immigrant students toward the use of clickers from the US perspective, Jones (2011) revealed that native-born students held more positive attitudes toward the technology than the immigrant students. Jones and George (2011) examined the faculty attitudes and revealed that faculties' (i.e., assistant, associate, and full professors) attitudes vary by rank. The findings indicated that full professors were less favorable toward the technology because they have less inclination to adopt new technology. 
Moreover, Kullven and Westin (2012) in the management context and Sprague and Dahl (2010) in the marketing context also advocated the positive attitude of students to the use of clickers in the classroom.

\subsection{Anonymity and ease of use}

The anonymity linked with clickers allows students to willingly use this technology to answer more sensitive questions and to take controversial positions on issues (Carnaghan et al., 2011). The ease of use makes sure that the clickers are used without any technical problem and handling issues. Five studies on anonymity and four on ease of use with three of them commonly discussing both these themes together indicate how closely they are linked. For example, the findings of Guthrie and Carlin (2004), Heaslip et al. (2014), and Matestic and Adams (2008) suggested that students generally appreciated anonymity and ease of use for better participation using clickers in the class. However, Guthrie and Carlin (2004) also revealed that a fair percentage of students were not worried about being judged poorly by their peers while answering incorrectly in the classroom. Moreover, Koppel and Berenson (2008) and Sprague and Dahl (2010) also largely supported the anonymity in clicker use. However, these studies have not given counterarguments if anonymity is not provided. Based on the literature regarding clickers, Keough (2012) found that students considered clickers as an easy-to-use tool.

\subsection{Student attendance}

Clickers automate the attendance process by collecting and storing the data answered by students. Using clickers to analyze grades eliminates extra effort that the instructor would have to make to take attendance at the beginning of each class (Bain and Przybyla, 2009). Seven studies (see Table 2) explore the theme of student attendance using clickers. Bain and Przybyla (2009) asserted that clickers enhanced the attendance of the majority of students. Out of 24 studies on attendance in a multidisciplinary literature review on clickers, Keough (2012) found that 19 reported high levels of student attendance. These findings seem to provide strong support for attendance. Also, Nelson and Hauck (2008) found that classes with clickers experienced greater attendance levels. Kullven and Westin (2012) linked the attendance check with the learning outcome and found that only $16 \%$ students from industrial management and $45 \%$ from management control agreed with the fact that the attendance check did influence their learning.

However, Dunnett et al. (2011) explored the attendance for users vs. non-users of clickers and found that attendance levels were significantly higher for students who did not use clickers. This result is not surprising, as in the absence of incentives, the use of clickers did not significantly increase class attendance (Dunnett et al., 2011). This finding is similar to the one obtained by MacArthur and Jones (2008), who found that many students responded negatively to the use of clickers when they were used only for the purpose of taking attendance. Carnaghan et al. (2011) also believed that using clickers only for taking attendance would invite criticism from students and therefore they would also miss out on more important benefits of this technology. 


\subsection{Student motivation and attention}

Jones (2011) in the context of the business stream found that the native-born students from the United States got more motivated to learn and link ideas using clickers than the immigrant students. Marshall and Varnon (2012) in the accounting context, Nelson and Hauck (2008) in the MIS context, and Thoms and Williams (2010) in the business context found that use of clickers enhanced students' motivation. However, these studies have not provided any further discussions on which aspects of clicker use improve student motivation or any downside of clickers, which might affect student motivation adversely. Some studies (e.g., Buyukkurt et al., 2012; Keough, 2012; Marshal and Varnon, 2012) also explored student attention through the use of clickers. Buyukkurt et al. (2012) stated that a CRS proved to be effective in facilitating a professor to accomplish her goals by increasing attention and reducing distraction in class. However, the study does not talk about how the technology helps the instructor in accomplishing this goal. Based on the prior literature on clickers, Keough (2012) found that the majority of classes using clickers had a high level of student attention span. Marshall and Varnon (2012) in the context of accounting also found that clickers helped students to maintain their attention. However, almost $20 \%$ of the overall students did not believe that clickers help them in focusing more on their studies.

\subsection{Effectiveness of clickers}

Only three studies analyzed the effectiveness of clickers in the business and management discipline. For example, Lojo (2009) finds that specific details of implementation can make a significant distinction in the effectiveness of clickers. The author argues for the need for more research to determine a greater effectiveness of clickers as this study was conducted using just one class with one professor. Humphries and Whelan (2009) examined the effectiveness of a PRS in enhancing student learning. Significantly positive responses to the questions measuring clickers' effectiveness indicate that the PRS improves students' learning. Given the mixed results from the literature and neutral findings from the study, Snavely and Chan (2008) in the context of the finance discipline concluded that effectiveness of clickers appears to be discipline specific.

\subsection{Some other under-represented clicker themes}

The review of relevant literature indicates that themes such as confidence (Chui et al., 2013), efficacy (Mula and Kavanagh, 2009), and security (Sprague and Dahl, 2010) have been discussed in only one study each and are not shown in Table 2. For example, Chui et al. (2013) reported that students using an SRS were found to be more confident in their abilities and spent less time preparing for the course material outside the class hour. Mula and Kavanagh (2009) found exploratory evidence of the efficacy of clickers to enhance student engagement and learning. However, the study does not discuss the ways in which the efficacy of the technology is improved. Sprague and Dahl (2010), although inform that a clicker provides anonymity and security, which make it an excellent tool, do not discuss what different security aspects it provides. 


\section{Discussion}

Out of 33 articles reviewed, one article was published in the year 2004 whereas the other 32 were published in the span of eight years from 2007 until 2014. This indicates that research on clicker technology in the business and management discipline is not that old and has just started to emerge in the last decade. Of the 33 studies overall, published between 2004 and 2014, 22 were undertaken in the USA, six in Canada, two in Australia, and one each in Ireland, Spain, and Sweden (see Appendix [B] for detailed information). The review of 33 studies indicated a number of themes (see Table 2 for details) that highlight the effect of clicker use on student and/or instructor perceptions/outcomes in more than one study. However, the other themes (not presented in Table 2), such as confidence, efficacy, and security, are also investigated but used in only one study each. Exploring such underrepresented clicker themes might add to the existing knowledge of clicker use in some way. Figure 1 presents the visual depiction of various issues being discussed using different clicker themes as reviewed in the literature.

The majority of studies (e.g., Heaslip et al., 2014; Slauson, 2011) on the use of clickers have shown that students feel more engaged using this technology than with the traditional method of teaching. However, some other studies (e.g., Fryling, 2013; Slauson, 2011) have also advocated the use of additional tools such as Excel and ticket systems along with clickers to keep the students more engaged. However, yet other studies (e.g., Carnaghan and Webb, 2007) found a moderately significant decline in students' engagement when a GRS is used, as students tend to ask fewer questions in such circumstances. From the detailed review of literature on clickers for student engagement, it can be concluded that when clickers are implemented well in the teaching and learning process, this generally improves students' engagement, but it also reduces the students' tendency to ask questions during the lecture and hence their engagement to a certain extent. We can argue that the instructor should change his/her tactics depending on the level students are able to become engaged themselves when using clickers. There is always a small minority of students who do not like their use (Carnaghan et al., 2011) in the classroom. The instructor needs to find ways in which he/she can engage all students irrespective of their likes or dislikes for clickers. Student engagement is an increasingly significant aspect of higher education learning. Hence, engaging students in the programmes and offering perceived value for money is very much warranted. The instructor can bring students to the forefront of research-engaged teaching and learning, where students are encouraged to create and develop new knowledge in collaboration with their instructor. In other words, student engagement can be realised only when it goes beyond just their involvement and consultation to reach further toward students being producers and change-agents to create a much richer and more valuable engagement (UL, 2012). 


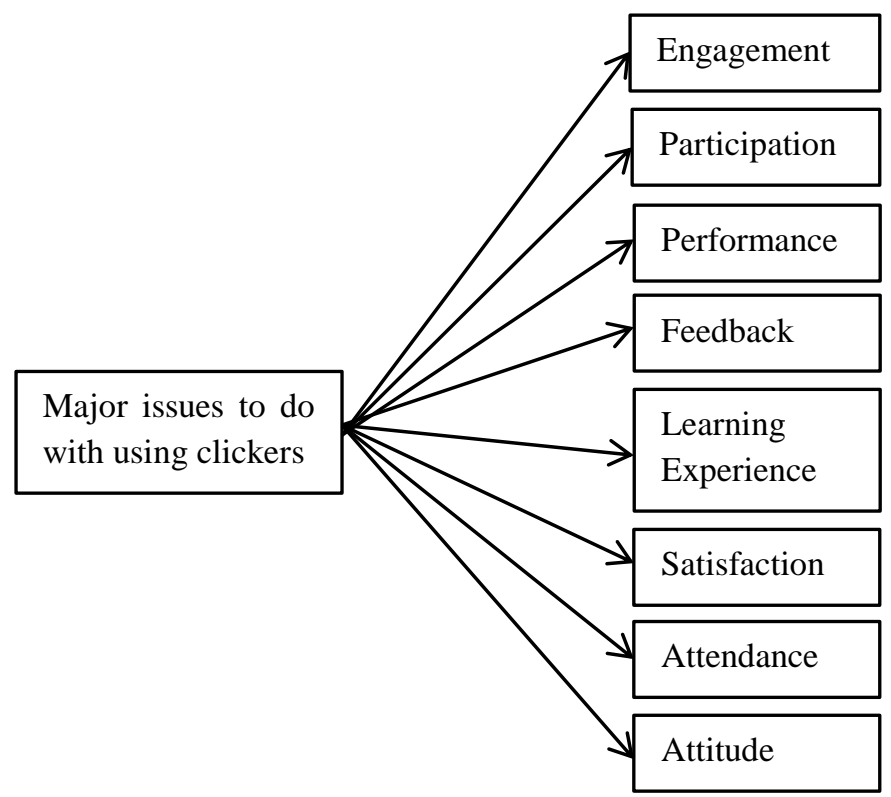

Figure 1. Major issues to do with using clickers discussed

Some studies (e.g., Bain and Przybyla, 2009; Guthrie and Carlin, 2004; Keough, 2012; Matestic and Adams, 2008) found participation to be one of the key elements of clicker use. Such studies reported that the use of clickers encouraged higher levels of student participation in the classroom. However, few other studies posed questions on the issue of participation where it was argued that a clicker only promotes implicit participation due to its anonymity (Thoms and Williams, 2010) that results in lack of interactivity whereas another study argued along similar lines that clickers do not seem to provide students with any opportunity to take notes and their involvement in discussions (Bain and Przybyla, 2009). Instead of finding improvement in participation, some research (i.e., Carnaghan and Webb, 2007), in fact, found that student participation actually decreased, particularly when most students answer the questions correctly. A similar finding was noted by other researchers (Morse et al., 2010), where either a modest increase or no enhancement in participation was found when an SRS was used to ask a discussion question at the start of each lecture.

From the above discussions, we conclude that to enhance the further participation of students, the instructors should ensure that they include sufficiently difficult and conceptual questions and a variety of these. Moreover, the questions asked by the instructors should have flexibility and variability to keep students interested and thinking about them (Carnaghan et al., 2011). Asking conceptual and difficult questions compel students to think more about them and hence will enhance their participation. The instructors should encourage students to participate by not only making their anonymous and silent responses through clickers but also interacting with them and by further exploring the arguments behind their responses to such questions, which do not have any right or wrong answers. Such questions can encourage more discussions in favor or against the broader aspects of the topic under consideration, which stretches students' thinking and imagination level and prepares them more toward gaining a better understanding of the course materials. Moreover, as clickers are also criticised for not providing enough time for students to take important notes of the topic under discussion (Bain and Przybyla, 2009), instructors should take proper care to provide ample opportunity for students to take notes of some of the critical concepts alongside 
deliberations so that they can recall these easily later. Such a strategy will also help instructors to improve student participation.

Performance is the next most explored element in business and management studies. The majority of studies (e.g., Bain and Przybyla, 2009; Hedgcock and Rouwenhorst, 2014; Hoanca, 2013) exploring performance advocated that clicker use has enhanced student performance in some form whereas other studies (e.g., Blasco-Arcas et al., 2013; Marshall and Varnon, 2012) are of the opinion that use of clickers alone does not increase performance. Such studies (e.g., Blasco-Arcas et al., 2013; Marshall and Varnon, 2012) argue that the use of clickers combined with peer practices and support can enhance student performance. Hence, the review indicates a mixed response on this question. Business educators should encourage more peer involvement, frequent course performance checks, and analysis of exam performance to analyze whether use of clickers has enhanced learners' performance. A comparison of perceived vs. actual performance can also show the real picture regarding performance (Keough, 2012). Although studies (e.g., Keough, 2012) support the exam performance of students who used clickers in comparison to those who did not use them, there is a further need to consolidate this finding. Future research can also develop a research model and perform some quantitative analysis considering the relevant measures of the factors including participation, engagement, and interactivity to see whether they have significant impact on learners' performance.

Although the literature (e.g., Blasco-Arcas et al., 2013) on the use of clickers suggests that it enhances students' perceived or learning performance, it is largely silent on whether this technology has helped students enhance exam performance. In order for clickers to be the reason for students' enhanced performance in exams, they should be used as a means of supporting students' deep learning rather than surface learning. This can be achieved only when they are used to create questions that support critical thinking and reflections rather than supporting immediacy. For example, the instructor can discuss a specific case, and clickers can be used to pose some open-ended questions that support few options whose selections are based on the in-depth analysis of the case. Although such questions might have certain options, their selection should be based on detailed discussion. That gives students an opportunity to get deeply involved in the various aspects of the case and understand the theme completely, rather than using clickers to answer some questions which have fixed answers and that do not extrapolate any further discussion. Therefore, using clickers to explore and discuss themes in depth with peers and the instructor can really enhance students' performance. Students' exam performance can then be measured from their grades obtained in the exam.

Further, clicker use allows the learners to get instant feedback on the course being taught or the multiple-choice tests organised to gauge their understanding levels of the course materials (Hedgcock and Rouwenhorst, 2014; Koppel and Berenson, 2008; Lincoln, 2007; Nelson and Hauck, 2008; Thoms and Williams, 2010). Although some studies (e.g., Mula and Kavanagh, 2009) have argued that two-way feedback provides instructors with a mechanism to dynamically change the delivery of material to meet the requirements and understanding of the specific cohort of students, such studies have not been found to emphasise how the 
instructor should adopt the appropriate strategy to teach students in a different way if the student feedback is varying and indicates poor understanding of the course content by a particular section of the class.

Further studies on clickers should come up with some successfully adopted examples of change strategies in the context of the above issue. The university management should also formulate some strategies to deal with such situations to expedite the feedback process and to inform students continuously about their performance in the various classes periodically. For example, the individual feedback of different modules can be gathered by the university central office and should be collectively sent through graphical presentations to students' email on a weekly basis so that they can easily understand their performance periodically. The comparative weekly feedback would allow students to comprehend their overall performance on the subject within a specific time period and provide them with an excellent opportunity to reflect on their understanding of the subject matter and raise any concerns with the corresponding instructors in good time. The feedback also allows the instructor to change his/her tactics and teach and discuss the course materials differently. The instructor can use the immediate feedback provided by clickers to dynamically alter the class in reaction to the nature and distribution of answers given by the students in class (Yourstone et al., 2008). The instructor should attempt all possible ways of doing this and stick to the teaching methodology that gets him/her the best feedback possible among the alternative ones. The instructors can use clickers as a medium for obtaining overall feedback not only about what proportion of the class understands and is following the teaching material but also for exploring what students think about the instructor's teaching and their overall knowledge, qualities, and hold on the given subject area. It can then be reflected upon and teaching delivered in the future in a way that results in a better student experience and improved learning performance.

A moderate number of studies (e.g., Humphries and Whelan, 2009; Nelson and Hauck, 2008; Sprague and Dahl, 2010; Stagg and Lane, 2010) have also emphasised that the use of clickers enhances students' active learning experiences. It was argued that the use of clickers alone could not work as a panacea for improved learning. It is rather a well-prepared and motivated instructor (Koppel and Berenson, 2008) and open discussions among classmates (Bain and Przybyla, 2009) that facilitate improved learning and better understanding of the course material. These counterarguments indicate that the instructors should use clickers only as a dynamic interface tool to interact with the students and should not consider them to be everything that leads to a better student learning experience. Although some studies (e.g., Humphries and Whelan, 2009) found that the use of the clickers improved students' perceived learning and the interactive nature of the technology made it appealing, it was also observed that there is limited evidence to support the astounding improvement in student learning that emerges with the use of the clickers. Some studies (e.g., Kang et al., 2012) have explored the gender effects on the use of clickers and their subsequent impacts on respondents. However, the results are still largely inconclusive. Given that clickers are a very recent technology, it is not surprising that only a few studies have examined the interaction between gender and clicker technology. Some studies suggest that students' gender and race 
do not influence their efficacy and use of clicker technology, and hence it may be considered equally beneficial to a wide population of students (MacGeorge et al., 2008). Other studies report that female students are particularly positive about the use of clicker technology, and use of such technology was found more favorable for women (Kang et al., 2012). These studies indicate that female students tend to participate better using clicker technology than the male students (e.g., King and Joshi, 2008). There is a need for further research to understand whether the gender differences can make any differentiation in the overall learning experience of students, particularly in the business and management stream. Realising the increasing participation of female students in the business and management stream and the inconclusive overall outcomes as to whether there is more support for the use of clicker technology from female students rather than male, it becomes extremely important for researchers to pay further attention to this. They should suggest to institutions and instructors the way forward to deal with these two cohorts of students differently in the same class, so that they can receive equal benefits from the use of this technology.

Some other studies (e.g., Carnaghan and Webb, 2007; Koppel and Berenson, 2008; Sprague and Dahl, 2010) advocated the high level of students' satisfaction when the clicker technology is used in comparison with when it is not used. For example, consistent with the prior research, some findings indicated strong student satisfaction with the clicker technology (Carnaghan and Webb, 2007) whereas others confirmed the substantial role of instructors in student satisfaction (e.g., Koppel and Berenson, 2008). It was recommended that faculties should be adequately trained and prepared to get positive student satisfaction. If members of faculty were unable to present the clicker questions properly and control the allocated time period available to complete each question, students' frustration levels and their dissatisfaction with clickers would increase (Koppel and Berenson, 2008). However, it was argued that a poor deployment of technology could lead to student dissatisfaction (Carnaghan and Webb, 2007).

Business educators should ensure that the clickers are properly installed with no technical glitches and they are aware of the proper functioning of this technology before its actual use in the classroom. Particularly, new faculty members should be given relevant training on the proper handling of the system to enhance student satisfaction. The instructors should also keep in mind that a small fraction of students would not be satisfied with the use of the clickers. Their experience can be improved by changing lecture content, adopting the inclusive method of teaching involving everyone in the class, and enhancing the class interactivity to bring everyone to the same level. Such teaching methods will help improve the understanding of those students who somewhat do not understand the course content to the level of those who comprehend and enjoy it and hence enhance their satisfaction levels.

Moreover, the use of clickers is also found to enhance students' attendance levels (e.g., Nelson and Hauck, 2008), attitude toward learning (e.g., Eastman et al., 2011), motivation (e.g., Thoms and Williams, 2010), anonymity (e.g., Heaslip et al., 2014) while providing feedback or answering sensitive questions, ease in using (e.g., Keough, 2012) the technology, and attentiveness (e.g., Buyukkurt et al., 2012). There is also criticism of studies supporting the use of clickers for improved attendance. Other studies argue that using clickers merely for 
taking attendance was even criticised by students (Carnaghan et al., 2011; MacArthur and Jones, 2009) and resulted in significant decrease in class attendance in comparison to nonusers (Dunnett et al., 2011). These findings indicate that the instructor should not use clickers only for taking attendance. They should rather use them for a better overall student learning experience and to promote satisfaction with this technology. Using clickers merely to improve attendance could be a time-saving mechanism for a large class, but it can be considered as undermining the capability of this technology if it is limited to taking attendance. We also believe that students may not find it motivating when clickers are used only for attendance purposes. It might rather give rise to complexity while it is used for taking attendance, particularly in a large class. Some students might forget to bring the clickers whereas others could miss it because they were not available during the specific time when the attendance was taken. The university should rather use sensors that could automatically capture student numbers, as soon as students enter the classroom, from the tag, which could be linked to anything that a student brings to the class. The other alternative is to record the attendance manually using the attendance register/sheet.

Moreover, we can also argue that although the clickers can enhance student motivation, attitude toward learning, and attentiveness, the technology has certain limitations, and the role of instructors becomes more critical to keep students continuously attentive and motivated toward their studies. An instructor should follow up from the point where students use the technological device to interact with them. The instructor can then create an appropriate strategy to firstly explain the concepts clearly and then create student groups to debate the questions arising from the topic.

Although the above discussions on the various themes relating to the use of clickers in the classroom largely consider clickers as a supporting device to promote student engagement, performance, participation, learning, feedback, satisfaction, attendance, enjoyment, anonymity, interaction, motivation, attention, etc., the criticism of clickers also raises a number of questions as far as the role of this technology in teaching and learning is concerned. For clarity of readers, Table 3 presents the advantages and disadvantages of clickers for some of the key themes demonstrated in Table 2. The clickers have been established as a tool to engage students by involving them in discussions through various questions raised on the topic and inviting their opinions on it during the class. However, it can also be debated as being a disruptive tool which might divert or distract student attention in the class. We can also argue that asking some questions using clickers and seeking students' response to them does not necessarily constructively attract their attention to the subject. Such a process could be useful for those students who get distracted during the lecture and need some specific questions and the subsequent discussions on them to keep them on track. However, the clickers cannot be proved equally advantageous for all the students in the class.

Table 3. Summary of the advantages and disadvantages of using clickers related to the major themes

\begin{tabular}{|l|l|l|}
\hline \multirow{2}{*}{ Theme } & $\begin{array}{l}\text { Advantage/Disadvantage of Using } \\
\text { Clickers }\end{array}$ & Supporting Source(s) \\
\hline Engagement & Students feel more engaged & Heaslip et al. (2014); Slauson (2011) \\
\cline { 2 - 3 } &
\end{tabular}




\begin{tabular}{|c|c|c|}
\hline & $\begin{array}{llll}\begin{array}{l}\text { Significant } \\
\text { engagement }\end{array} & \text { decline in } & \text { students' } \\
\end{array}$ & Carnaghan and Webb (2007) \\
\hline \multirow[b]{2}{*}{ Participation } & $\begin{array}{l}\text { Encourages higher levels of student } \\
\text { participation }\end{array}$ & $\begin{array}{l}\text { Bain and Przybyla (2009); Guthrie and Carlin } \\
\text { (2004); Keough (2012); Matestic and Adams } \\
\text { (2008) }\end{array}$ \\
\hline & $\begin{array}{l}\text { [1] Clickers do not provide students with } \\
\text { any opportunity to take notes and become } \\
\text { involved in discussions } \\
\text { [2] Decreased participation }\end{array}$ & $\begin{array}{l}\text { [1] Bain and Przybyla (2009) } \\
\text { [2] Carnaghan and Webb (2007); Morse et al. } \\
\text { (2010) }\end{array}$ \\
\hline \multirow{2}{*}{$\begin{array}{l}\text { Learning } \\
\text { Experience }\end{array}$} & Enhances student learning experience & $\begin{array}{l}\text { Humphries and Whelan (2009); Nelson and } \\
\text { Hauck (2008); Sprague and Dahl (2010); Stagg } \\
\text { and Lane (2010) }\end{array}$ \\
\hline & $\begin{array}{l}\text { The use of clickers alone cannot work as a } \\
\text { panacea for improved learning }\end{array}$ & $\begin{array}{l}\text { Bain and Przybyla (2009); Koppel and } \\
\text { Berenson (2008) }\end{array}$ \\
\hline \multirow{2}{*}{ Performance } & Enhanced student performance & $\begin{array}{l}\text { Bain and Przybyla (2009); Hedgcock and } \\
\text { Rouwenhorst (2014); Hoanca (2013) }\end{array}$ \\
\hline & $\begin{array}{l}\text { The use of clickers alone does not increase } \\
\text { performance }\end{array}$ & $\begin{array}{l}\text { Blasco-Arcas et al. (2013); Marshall and } \\
\text { Varnon (2012) }\end{array}$ \\
\hline \multirow[b]{2}{*}{ Feedback } & $\begin{array}{l}\text { Clicker use allows the learners to get } \\
\text { instant feedback }\end{array}$ & $\begin{array}{l}\text { Hedgcock and Rouwenhorst (2014); Koppel and } \\
\text { Berenson (2008); Lincoln (2007); Nelson and } \\
\text { Hauck (2008); Thoms and Williams (2010) }\end{array}$ \\
\hline & $\begin{array}{l}\text { Not of much use to those who [1] tend to } \\
\text { get everything right all the time or [2] are } \\
\text { not interested in responding to questions or } \\
\text { perform worst every time }\end{array}$ & Lincoln (2007) \\
\hline \multirow{2}{*}{ Satisfaction } & $\begin{array}{l}\text { The use of clickers provides high levels of } \\
\text { student satisfaction }\end{array}$ & $\begin{array}{l}\text { Carnaghan and Webb (2007); Koppel and } \\
\text { Berenson (2008); Sprague and Dahl (2010) }\end{array}$ \\
\hline & $\begin{array}{l}\text { Limited evidence of satisfaction in case of } \\
\text { poor use of technology }\end{array}$ & Carnaghan and Webb (2007) \\
\hline \multirow[b]{2}{*}{ Attendance } & Enhanced attendance level & Nelson and Hauck (2008) \\
\hline & Significant decrease in class attendance & $\begin{array}{l}\text { Dunnett et al. (2011), MacArthur and Jones } \\
\text { (2008) }\end{array}$ \\
\hline \multirow[b]{2}{*}{ Attitude } & High attitude toward using clickers & Eastman et al. (2011) \\
\hline & $\begin{array}{l}\text { Experienced teaching faculty such as full } \\
\text { professors are less favorable toward using } \\
\text { clickers because they are less inclined to } \\
\text { adopt new technology }\end{array}$ & Jones and George (2011) \\
\hline
\end{tabular}

Further, it can also be argued that clickers as a classroom response system are primarily used to promote immediacy rather than allowing reflection. The students are required to respond to the specific questions immediately after they are taught a topic to get instant feedback of their understanding of it. The feedback obtained through this technology is so quick that it tells students whether they understood the discussed topic or not almost instantly and hence provides hardly any time for reflection on their learning. It has been argued that reflection increases student motivation, confidence, and general interest in the subject area (Boud, 1995; Hinett and Thomas, 1999; Orsmond et al., 2002). As it can be argued that the use of clickers in teaching and learning does not allow for reflection, it would largely encourage surface learning rather than deep and engaged learning of the course content. Therefore, it can be asserted that learning through clickers complemented by reflective practices would have a more in-depth impact on student learning experience. For example, if the clickers are used to discuss theoretical aspects of any business-related module with a case that uses the taught theoretical knowledge of the course content already covered, and students are asked to prepare answers for such questions arising from the case study, they would be bound to 
reflect on the course material that they have learned in order to correctly answer the questions. In such a scenario, clickers would promote reflection rather than immediacy.

Furthermore, the use of clickers in the classroom might also diminish the possibility of group discussion and team working, as students tend to interact largely with the instructors and less among themselves in reality. However, it can also be argued that the use of clickers can promote group discussion and team working on the other hand. This is possible when the instructor asks a question from a topic during the lecture where the answer is not fixed and is subject to debate and discussion. The instructor can then form groups of students as per their similarity of opinions and encourage them to discuss the answer with their appropriate justification. So, the technology in itself is not enough; it is the instructor who is able to design and create such questions that promote group discussions and team working.

The use of clickers by universities is also a strategy for entertaining and educating the students at the same time. This overall strategy could be termed as 'edutainment' ${ }^{2}$ (i.e., education and entertainment), which is primarily centered on returning something useful to the students (who can be considered as consumers for the university business); they come and enrol on the professional university courses by paying a very high fee, and therefore expect something in return. Teaching through technology such as clickers not only makes the class interesting but it can also be considered as a "crowd control' ${ }^{3}$ mechanism in the case of largeclass teaching. Considering the critical review of literature on clickers and analyzing the possible criticisms of what clickers can lead to allows us to conclude that where clickers on the one hand provide a number of advantages to students in terms of student engagement, participation, motivation, learning, feedback, satisfaction, attendance, performance, etc. to a certain extent, on the other hand, they are also used as an educational gimmick by the modern educational institutions to attract and entertain students on their respective courses.

\subsection{Current literature review vs. earlier literature reviews on clickers}

Comparing the outcomes of literature from the business and management discipline to those of the other disciplines on the use of clickers indicates that almost all themes/outcomes obtained are similar to the one explored in this literature review. For example, Keough (2012) reviewed 66 multidisciplinary studies based on clicker technology focusing on student perceptions and found some key outcomes including high levels of performance, attention span, attendance, participation, satisfaction, feedback, and ease of use. Realising the lack of literature in management, the author also conducted empirical research in the business and management context and found that the outcomes were similar in this discipline as well. The current research also largely supports Keough's (2012) empirical findings. Gagne (2011) presented a review of 15 empirical studies of clicker use in nursing, medical, pharmacy, and paramedical education and addressed key characteristics of clicker use such as interactivity and participation, satisfaction and learning outcomes, and formative assessment and

\footnotetext{
${ }^{2}$ This idea has come from an anonymous reviewer.

${ }^{3}$ This idea has come from an anonymous reviewer.
} 
contingent teaching. The findings concluded that use of clickers enhanced not only learners' satisfaction but also their engagement and participation with the course.

Based on the review and synthesis of experimental literature on SRSs, Carnaghan et al. (2011) found clear evidence of student satisfaction and engagement. MacArthur and Jones (2008) performed a literature review of 56 studies on the practical use of clickers in collegelevel science classrooms and suggested that the students had a positive attitude toward the technology with a number of benefits and a few drawbacks associated with it. The most widely recognised benefits of clickers were as a formative assessment tool and as a means to promote student cooperation. The most widely recognised drawbacks were the need for student adjustment, time limitations, and technology issues. The current literature review on the business and management discipline widely covered the outcomes of literature reviews performed across various disciplines earlier. However, characteristics such as student collaboration has not been highlighted in the literature of the business and management discipline. Also, one study (i.e., Keough, 2012) from multidisciplines has highlighted the technical issues of clickers in the classroom; no other literature review has much emphasised the weaknesses of clickers as such.

This literature provides a contribution to the existing knowledge as it only reviews literature from the business and management discipline and provides a synthesis of the outcomes emerging from it. It is different to the literature review undertaken by Keough (2012) as it provides a review of all disciplines except management indicating that there are only a handful of studies available in the business and management discipline. Despite the multidisciplinary review, Keough (2012) has highlighted only a handful of themes such as performance, satisfaction, attention span, attendance, participation feedback, and ease of use. However, the current research has analyzed its view on many other themes including student engagement, learning, attitude, enjoyability, anonymity, motivation, interactivity, assessment, understanding, and clickers' effectiveness in addition to those explored by Keough (2012). This difference in the review opens a further avenue for the literature analysis to widely adopted studies from various disciplines or even to the literature of specific streams.

\subsection{Effective use of clickers: learning from existing studies}

As the research studies conducted on the use of clickers in business and management are only a decade old and moderate in number, there is a further need for learning from more mature research from other disciplines, which have not yet implemented in the business and management area. For example, Gain (2013) in the context of computer science claimed that clickers are relatively expensive, particularly from the perspective of developing countries, and presented an inexpensive alternative to clickers. The students hold up a poll sheet with coloured blocks printed on a white background and a camera phone is used in panoramic mode to photograph the class. This image is then processed using computer vision to count and classify students' responses. Although this system was not found to be as accurate as clickers, this approach nevertheless had many of the similar benefits for active learning at significantly less cost than clickers. This approach could be appropriate where cost is the 
deciding factor or instructors wish to examine polling before committing to a complete clicker solution.

Moreover, instead of using ordinary hardware clickers, Hauswirth and Adamoli (2013) prescribed the use of software clickers implemented in Java to teach Java programming, which allows solving much richer problem types than the traditional multiple-choice questions. Use of such clickers allows the students a much higher degree of freedom in solving a problem and learning from the mistakes of their peers. Similarly, JackowskaStrumillo et al. (2013) also presented a concept of using clicker software, which can run on a mobile, tablet, PDA, or PC. Such solutions offer flexible student-instructor interaction.

Also, Robbins (2011) introduced a new classroom response system called ClassQue that goes beyond clickers to allow an extensive selection of classroom interactions: teacher to individual student, teacher to all students, student to teacher, and student to student. Questions using this tool were not limited to multiple choice and rather multiple questions could be pending at one time. One student could anonymously comment on other student's responses. After the completion of the class, students and teacher could receive the report of the classroom interactions. However, the existing version of ClassQue was available for use in environments where every student is seated at the computer (Robbins, 2011). The studies on the business and management discipline can also implement the specified forms of clickers as cost-effective and complex-problem solving alternatives. Students of business and management can use any other electronic devices (such as smartphones, tablets, PCs, PDAs etc.) with clicker software to provide more flexible clicker solutions.

Barber and Njus (2007) introduced and compared six different types of clicker systems that are available on the market, including eInstruction Classroom Performance System, Quizdom, TurningPoint, Interwrite PRS, iClicker, and H-ITT and discussed the factors that should be considered in making an appropriate selection of clickers for a specific discipline. Kang et al. (2012) examined gender differences in science learning between two academic approaches: traditional lecture and narrative case studies using clickers. It was also suggested that the selection of a clicker system should be driven by the faculty, although consent from students and the relevant teaching and technology support units must also be taken into consideration. Selection of an appropriate clicker system should be sought to deliver the lecture in the best and most efficient way possible rather than finding ways to use the imposed clickers to conduct business courses in the university setup. The top management of the business schools and their faculties should probably evaluate the pros and cons of all forms of clickers to analyze their best suitability for the business courses, and the most effective clickers could probably be picked up for further use.

\subsection{Recommendations from the business and management literature}

Studies (e.g., Bain and Przybyla, 2009; Carnaghan et al., 2011; Jones, 2011; Sprague and Dahl, 2010) from the business and management discipline have provided some invaluable recommendations for practice. Such suggestions must be considered and effectively 
implemented using clickers in the classroom setting. For example, Sprague and Dahl (2010) recommended that clicker technology needs to be incorporated throughout the body of the lecture discussion. It was also suggested that an important aspect to keep in mind is not to overboard this technology in the classroom. Jones (2011) suggested that instructors should be more conscious of potential differences among students. Instructors should carefully contemplate whether the clicker experience is relatively significant for all students, particularly in a situation where a class comprises students from different backgrounds and cultures. Bain and Przybyla (2009) provided a similar recommendation where they suggested that instructors carefully assess the teaching style and nature of the course before using clicker technology.

As with any teaching methodology, some students might attempt to cheat the system. Therefore, it is suggested that instructors compare the number of responses with the number of students in the class to avoid any misconduct. This is particularly important in cases where clickers are used in the class for grade evaluation purposes. Further, students with disabilities may need specialised applications for the implementation of clickers. Hence, instructors should seek appropriate guidance to take all students along with them in the use of this technology (Carnaghan et al., 2011). Our experience of using clicker technology in the class indicates that it creates an unpleasant situation in cases where it stops working in the midst of functioning. The instructors should always keep an alternative support system ready to overcome such situations. It has also been seen that some clicker devices do not work during the time of taking attendance, feedback, or even a class test, or sometimes a few students forget to bring the clicker to the class. To avoid such awkward situations, the instructors should even be ready to take responses manually on paper.

Also, studies such as Blasco-Arcas et al. (2013) and Marshall and Vernon (2012) have advocated that using clickers as technology is not enough to improve students' overall performance in the class. The students' performance also depends to a larger extent on peer involvement and discussions of the course materials. The instructors are therefore recommended to encourage peer instruction and discussions along with the use of clicker technology to improve student performance. Along the lines of how to successfully teach students with physical and learning disability that restricts their ability to use clickers, Carnaghan et al. (2011) recommended that the instructors should seek guidance from experts at their individual institutions toward resolving particular challenges linked to these students.

\section{Conclusion}

The purpose of this article was to review the literature on the use of clickers to find out what implications could be drawn for the business and management discipline. The review of literature has uncovered that clickers have the exclusive capabilities to not only enhance students' engagement, performance, learning, satisfaction, and motivation but also largely improve their participation, attendance, attitude, interactivity, and understanding of the course material. This article discussed a number of benefits associated with the use of clickers and their characteristics and addressed the need for business educators to take advantage of the latest technology to make teaching and learning more effective. The study also provided a 
critical review and discussion of clicker technology by highlighting some of the criticisms of it as well as its drawbacks. In addition, we highlighted some other shortcomings of clicker technology such as its likelihood to divert rather than focus students' attention, its propensity to highlight instantaneousness rather than reflection, or eliminate prospects for group discussion and team working ${ }^{4}$.

However, it was further debated that some of such criticisms of clickers can be largely overcome to a certain extent by considering the appropriate plans and strategies in place. For example, creating a case linked with the conceptualisation of theory can be used to promote reflection. Also, as the clickers promote students' interactions largely with instructors and hardly promote debate and discussions among students, the instructor can form groups of students with similar opinions about a topic to encourage peer discussions. Moreover, it should also be noted that clickers as a technology on their own are not sufficient to provide solutions to the emerging issues of teaching and learning in higher education. The higher education institutions in general and instructors in particular should also plan alternative ways of engaging and motivating students for their better learning experience. This literature review has also compared its findings with the review presented for some other specific and multidisciplinary research (e.g., science, computers, nursing, pharmacy, etc.) on the use of clickers and discussed its pros and cons in comparison to their outcomes. Although this literature review has been limited to the use of clickers in the business and management discipline, it has explored some other disciplines to learn lessons from them. Such research studies have suggested bringing in some alternative clicker systems to make the teaching in business and management even more effective and highly interactive in fashion.

\subsection{Limitations and future research}

Like other literature reviews, this study is not without limitations. Firstly, this research has collated studies only related to the business and management discipline at large. Future research should possibly perform a review considering the overall and most updated literature available on clicker technology. Secondly, as some quantitative studies have been conducted on the use of clickers in different disciplines in the last few years, this research could have used a meta-analysis approach to analyze some of the frequently used construct relationships, and their cumulative performance could have been analyzed across studies. Future research can use this meta-analysis approach to understand the overall performance of the interrelationships of constructs (e.g., engagement, feedback, interaction, performance, motivation, attendance, etc.). Thirdly, the number of studies chosen for performing a comprehensive review is relatively small in number. Future research should probably perform a review of all articles considered from different disciplines to understand whether the outcomes of such a literature review converges or diverges from the findings of this research.

Acknowledgement: We would like to acknowledge the valuable contributions of the reviewers and editor who have provided critical suggestions to improve the quality of the

\footnotetext{
${ }^{4}$ These shortcomings were noted earlier in the paper based on the anonymous reviewer's comments.
} 
paper. The suggested comments have helped us in improving the quality of the paper considerably.

\section{References}

Addison, S., Wright, A., \& Milner, R. (2009). Using clickers to improve student engagement and performance in an introductory biochemistry class. Biochemistry and Molecular Biology Education, 37(2), 84-91.

Bain, L.Z., \& Przybyla, J. (2009). The impact of student response systems on student behavior and performance in a management information systems course. Issues in Information Systems, 10(1), 1-12.

Barber, M., \& Njus, D. (2007). Clicker evolution: Seeking intelligent design. CBE-Life Sciences Education, 6(1), 1-8.

Barnett, J. (2006). Implementation of personal response units in very large lecture classes: Student perceptions. Australasian Journal of Educational Technology, 22, 474-494.

Bergtrom, G. (2006). Clicker sets as learning objects. Interdisciplinary Journal of E-Learning and Learning Objects, 2(1), 105-110.

Blasco-Arcas, L., Buil, I., Hernandez-Ortega, B., \& Sese, F. J. (2013). Using clickers in class. The role of interactivity, active collaborative learning and engagement in learning performance. Computers \& Education, 62, 102-110.

Bloom, B.S. (1956). Taxonomy of educational objectives: The classification of education goals by a committee of college and university examiners. David McKay.

Bonaiuti, G., Calvani, A., \& Piazza, D. (2015). Increasing classroom engagement and student comprehension through the use of clickers: an Italian secondary school experience. Research on Education and Media, 5(1), 95-108.

Boud, D. (1995). Enhancing learning through self-assessment. Kogan Page, London.

Bruff, D. (2009). Teaching with Classroom Response Systems: Creating Active Learning Environments. Jossey-Bass, San Francisco, CA.

Bullock, D. W., LaBella, V. P., Clingan, T., Ding, Z., Stewart, G., \& Thibado, P. M. (2002). Enhancing the student-instructor interaction frequency. The Physics Teacher, 40, 535-541.

Buyukkurt, M.D., Li, Y., \& Cassidy, R. (2012). Using a Classroom Response System in an Introductory Business Statistics Course: Reflections and Lessons Learned. Proceedings of Informing Science \& IT Education Conference, 379-388.

Caldwell, J. (2007). Clickers in the large classroom: Current research and best-practice tips. CBE-Life Sciences Education, 6(1), 9-20.

Carnaghan, C., \& Webb, A. (2007). Investigating the effects of group response systems on student satisfaction, learning, and engagement in accounting education. Issues in Accounting Education, 22(3), 391-409.

Carnaghan, C., Edmonds, T.P., Lechner, T.A., \& Olds, P.R. (2011). Using student response systems in the accounting classroom: Strengths, strategies and limitations. Journal of Accounting Education, 29(4), 265-283.

Chui, L., Martin, K., \& Pike, B. (2013). A quasi-experimental assessment of interactive student response systems on student confidence, effort, and course performance. Journal of Accounting Education, 31(1), 17-30.

Conrad, R.M., \& Donaldson, J.A. (2004). Engaging the Online Learner: Activities and Resources for Creative Instruction. John Wiley \& Sons, San Francisco, CA. 
Crossgrove, K., \& Curran, K. (2008). Using clickers in nonmajors- and majors-level biology courses: Student opinion, learning, and long-term retention of course material. CBE-Life Sciences Education, 7(1), 146-154.

De Gagne, J.C. (2011). The impact of clickers in nursing education: A review of literature. Nurse Education Today, 31(8), e34-e40.

Dunnett, A.J., Shannahan, K.L., Shannahan, R.J., \& Treholm, B. (2011). Exploring the Impact of Clicker Technology in a Small Classroom Setting on Student Class Attendance and Course Performance. Journal of the Academy of Business Education, 12, 43-56.

Eastman, J.K., Iyer, R., \& Eastman, K.L. (2011). Business students' perceptions, attitudes, and satisfaction with interactive technology: An exploratory study. Journal of Education for Business, 86(1), 36-43.

Finn, J.D., \& Rock, D.A. (1997). Academic success among students at risk for school failure. Journal of Applied Psychology, 82(2), 221-234.

Fryling, M. (2013). Click It and Ticket: Extending the benefits of clickers in small classrooms to increase non-anonymous class participation. In Proceedings of the Information Systems Educators Conference, 1-11.

Gain, J. (2013). Using poll sheets and computer vision as an inexpensive alternative to clickers. Proceedings of the South African Institute for Computer Scientists and Information Technologists Conference, 60-63.

Guthrie, R., \& Carlin, A. (2004). Waking the dead: Using interactive technology to engage passive listeners in the classroom. Proceedings of the Tenth Americas Conference on Information Systems, New York, USA.

Han, J.H., \& Finkelstein, A. (2013). Understanding the effects of professors' pedagogical development with Clicker Assessment and Feedback technologies and the impact on students' engagement and learning in higher education. Computers \& Education, 65, 64-76.

Hancock, T.M. (2010). Use of audience response systems for summative assessment in large classes. Australasian Journal of Educational Technology, 26(2), 226-237.

Hatziapostolou, T., Pupovci, T., Dranidis, D., Paraskakis, I., \& Ntika, M. (2014). Boosting the Pedagogical Value of Classroom Clicker Systems via the Provision of Formative Feedback. $14^{\text {th }}$ International Conference on Advance Learning Technologies, pp. 165-167.

Hauswirth, M., \& Adamoli, A. (2013). Teaching Java programming with the Informa clicker system. Science of Computer Programming, 78(5), 499-520.

Heaslip, G., Donovan, P., \& Cullen, J.G. (2014). Student response systems and learner engagement in large classes. Active Learning in Higher Education, 15(1), 11-24.

Hedgcock, W.H., \& Rouwenhorst, R.M. (2014). Clicking Their Way to Success: Using Student Response Systems as a Tool for Feedback. Journal for Advancement of Marketing Education, 22(2), 16-25.

Herreid, C.F. (2006). "Clicker" Cases: Introducing Case Study Teaching into Large Classrooms. Journal of College Science Teaching, 36(2), 43-47.

Hinett K., \& Thomas, J. (1999). Staff guide to self and peer assessment. Oxford Centre for Staff and Learning Development, Oxford.

Hoanca, B. (2013). How well do clicker scores correlate with course performance? A case study in two MIS courses. In Proceedings of the Information Systems Educators Conference, $1-9$. 
Humphries, S.A., \& Whelan, C. (2009). Effectiveness of Interactive Technology in Business Education. Business Education Innovation Journal, 1(2), 53-58.

Jackowska-Strumillo, L., Nowakowski, J., Strumillo, P., \& Tomczak, P. (2013). Interactive question based learning methodology and clickers: Fundamentals of computer science course case study. Sixth International Conference on Human System Interaction, 439-442.

Jones, K. (2011). Clickers Technology Attitudinal Differences Of Native-Born And Immigrant Students: What Are The Pedagogical Implications? In M.A. Goralski, H.P. LeBlanc III, M.G. Adams: Balancing Profitability and Sustainability: Shaping the Future of Business. Business Research Yearbook, XVIII(1), 280-286.

Jones, K., \& George, A.M. (2011). Clickers Technology Attitudes of Business School Faculty: Outcomes, Evaluations and Insights. In M.A. Goralski, H.P. LeBlanc III, M.G. Adams: Balancing Profitability and Sustainability: Shaping the Future of Business. Business Research Yearbook, XVIII(1), 287-293.

Kang, H., Lundeberg, M., Wolter, B., delMas, R., \& Herreid, C. F. (2012). Gender differences in student performance in large lecture classrooms using personal response systems ('clickers') with narrative case studies. Learning, Media and Technology, 37(1), 5376.

Kay, R.H., \& LeSage, A. (2009). Examining the benefits and challenges of using audience response systems: a review of the literature. Computers \& Education, 53, 819-827.

Keough, S.M. (2012). Clickers in the Classroom: A Review and a Replication. Journal of Management Education, $\mathrm{XX}(\mathrm{X}), 1-26$.

King, D. B., \& Joshi, S. (2008). Gender differences in the use and effectiveness of personal response devices. Journal of Science Education and Technology, 17(6), 544-552.

Koenig, K. (2010). Building acceptance for pedagogical reform through widescale implementation of clickers. Journal of College Science Teaching, 39(3), 46-50.

Koppel, N., \& Berenson, M. (2009). Ask the audience - Using clickers to enhance introductory business statistics courses. Information Systems Education Journal, 7(92), 1-18.

Kullven, H., \& Westin, T. (2012). Clickers in Education: Do students' perceptions of clickers differ with the purpose? FEKIS 5 Conference, Sweden.

Lai, G., Hill, V., \& Ma, Y. (2015). Clickers in the classroom: a business professor's adoption of a classroom response system. International Journal of Innovation and Learning, 18(4), 451-470.

Lincoln, D. (2007). Using student response pads ('clickers') in the principles of marketing classroom. In Proceedings of the 2007 ANZMAC Conference (3328-3333).

Lincoln, D. (2008). Teaching with clickers in the large-size principles of marketing class. Marketing Education Review, 18(1), 39-45.

Lojo, M. (2009). A comparison of clicker effectiveness for multiple choice and quantitative questions. California Journal of Operations Management, 7(1), 130-135.

MacArthur, J.R., \& Jones, L.L. (2008). A review of literature reports of clickers applicable to college chemistry classrooms. Chemistry Education Research and Practice, 9(3), 187-195.

MacGeorge, E. L., Homan, S. R., Dunning Jr, J. B., Elmore, D., Bodie, G. D., Evans, E., Khichdia, S., Lichti, S., Feng, B. \& Geddes, B. (2008). Student evaluation of audience response technology in large lecture classes. Educational Technology Research and Development, 56(2), 125-145. 
Mareno, N., Bremner, M., \& Emerson, C. (2010). The use of audience response systems in nursing education: best practice guidelines. International Journal of Nursing Education Scholarship, 7, 1-17.

Marshall, L.L., Valdosta, G., \& Varnon, A.W. (2012). An Empirical Investigation of Clicker Technology in Financial Accounting Principles. Learning in Higher Education, 8(1), 7-17.

Matesic, M.A., \& Adams, J.M. (2008). Provocation to learn - A study in the use of personal response systems in information literacy instruction. Partnership: the Canadian Journal of Library and Information Practice and Research, 3(1), 1-14.

Morse, J., Ruggieri, M., \& Whelan-Berry, K. (2010). Clicking our way to class discussion. American Journal of Business Education, 3(3), 99-108.

Mula, J.M., \& Kavanagh, M. (2009). Click Go the Students, Click-Click-Click: The efficacy of a student response system for engaging students to improve feedback and performance. $e$ Journal of Business Education and Scholarship of Teaching, 3(1), 1-17.

Nelson, M.L., \& Hauck, R.V. (2008). Clicking to learn: A case study of embedding radiofrequency based clickers in an introductory management information systems course. Journal of Information Systems Education, 19(1), 55-64.

Orsmond, P., Merry, S., \& Reiling, K. (2002). The use of exemplars and formative feedback when using student derived marking criteria in peer and self-assessment. Assessment \& Evaluation in Higher Education, 27(4), 309-323.

Prather, E.E., \& Brissenden, G. (2009). Clickers as data gathering tools and students' attitudes, motivations, and beliefs on their use in this application. Astronomy Education Review, 8(1), 010103-0101110.

Premuroso, R.F., Tong, L., \& Beed, T.K. (2011). Does using clickers in the classroom matter to student performance and satisfaction when taking the introductory financial accounting course? Issues in Accounting Education, 26(4), 701-723.

Robinson, S. (2007). Engaging students through electronic response devices (clickers). Management Review: An International Journal, 2(1), 4-16.

Roblyer, M.D., \& Wiencke, W.R. (2003). Design and use of a rubric to assess and encourage interactive qualities in distance courses. American Journal of Distance Education, 17(2), 7798.

Salemi, M.K. (2009). Clickenomics: Using a classroom response system to increase student engagement in a large-enrollment principles of economics course. Journal of Economic Education, 40(4), 385-404.

Simpson, V., \& Oliver, M. (2007). Electronic voting systems for lectures then and now: a comparison of research and practice. Australasian Journal of Educational Technology, 23(2), 187-208.

Slauson, G.J. (2011). Using Easy Excel Tools with Clickers to Make Large or Small Classes on Any Subject Immediately Engaging. In Information Systems Educators Conference, Wilmington, North Carolina, USA.

Smart, D.T., Kelley, C.A., \& Conant, J.S. (1999). Marketing education in the year 2000: Changes observed and challenges anticipated. Journal of Marketing Education, 21(3), 206216.

Snavely, J.C., \& Chan, K.C. (2008). Do Clickers 'Click' in the Finance Classroom? Financial Management Association International, Tampa, USA. 
Sprague, E.W., \& Dahl, D.W. (2010). Learning to click: An evaluation of the personal response system clicker technology in introductory marketing courses. Journal of Marketing Education, 32(1), 93-103.

Stagg, A., \& Lane, M. (2010). Using clickers to support information literacy skills development and instruction in first-year business students. Journal of Information Technology Education: Research, 9(1), 197-215.

Strasser, N. (2010). Who wants to pass math? Using clickers in calculus. Journal of College Teaching \& Learning, 7(3), 49-52.

Thoms, C.L., \& Williams, H. (2010). Using student response systems (clickers) in redesigning a blended learning curriculum. In International Conference on Education, Research, and Innovation. Proceedings of ICERI Conference, Madrid, Spain.

Ueltschy, L. (2001). An exploratory study of integrating interactive technology into the marketing curriculum. Journal of Marketing Education, 23(1), 63-72.

UL (2012). Student Engagement Strategy 2012-16. University of Lincoln, United Kingdom. Accessed from https://www.lincoln.ac.uk/home/media/universityoflincoln/globalmedia/ documents/SES.pdf on January 24, 2016.

Yourstone, S. A., Kraye, H. S., \& Albaum, G. (2008). Classroom questioning with immediate electronic response: Do clickers improve learning? Decision Sciences Journal of Innovative Education, 6(1), 75-88.

\section{Appendix [A]: List of Journals}

Academy of Management, Learning Aids Education, Management Learning, Studies in Higher Education, British Educational Research Journal, Journal of Accounting Education, Journal of Higher Education, Journal or Education Policy, British Journal of Guidance and Counselling, Innovations in Education and Teaching international, Accounting Education, Advances in Developing Human Resources, Higher Education Quarterly, Journal of Management Education, Journal or Education and Work, Journal of Marketing Education, Issues in Accounting Education, Journal of European Industrial Training, Education and Training, Industry and Higher Education, Educational Management Administration and Leadership, Journal of Vocational Education and Training, Journal of Management Development, Active Learning in Higher Education, International Journal of Management Education, Journal of Further and Higher Education, Quality Assurance IS Education, International Journal of Training and Development, and Journal of Workplace Learning 
Appendix [B]. Observations made in publications on the use of clickers in business and management discipline (Adapted from: M

\begin{tabular}{|c|c|c|c|c|}
\hline Study & Themes & $\begin{array}{l}\text { Country of } \\
\text { Research }\end{array}$ & $\begin{array}{l}\text { Class/Sample } \\
\text { Size (CS) } \\
\end{array}$ & System Used \\
\hline Guthrie and Carlin (2004) & $\begin{array}{l}\text { Perception, Participation, Anonymity, } \\
\text { Easy to Use }\end{array}$ & USA & $\begin{array}{l}\text { CS1: } 65 \\
\text { CS2: } 74 \\
\end{array}$ & Audience Res \\
\hline Lincoln (2007) & $\begin{array}{l}\text { Instant Feedback, Easy to Use, Fun to Use, } \\
\text { Enjoyable }\end{array}$ & USA & 68 & Student Respo \\
\hline Robinsson (2007) & Engagement, Fun to Use & USA & 66 & Electronic Res \\
\hline Carnaghan and Webb (2007) & Satisfaction, Learning, Engagement & Canada & $\begin{array}{l}\text { CS1: } 128 \\
\text { CS2: } 183\end{array}$ & Group Respon \\
\hline Koppel and Berenson (2008) & $\begin{array}{l}\text { Instant Feedback, Fun to Use, Anonymity, } \\
\text { Satisfaction, Learning }\end{array}$ & USA & 105 & Radio-Freque \\
\hline Matestic and Adams (2008) & $\begin{array}{l}\text { Easy to Use, Anonymity, Participation, } \\
\text { Engagement, Assessment }\end{array}$ & Canada & $\begin{array}{l}\text { CS1: } 200 \\
\text { CS2: } 200\end{array}$ & Personal Resp \\
\hline Nelson and Hauck (2008) & $\begin{array}{l}\text { Performance, Attendance, } \quad \text { Active } \\
\text { Learning, Motivation, Feedback }\end{array}$ & USA & $\begin{array}{l}\mathrm{CS} 1=175 \\
\mathrm{CS} 2=65 \\
\mathrm{CS} 3=63\end{array}$ & Radio-Freque \\
\hline Snavely and Chan (2008) & Effectiveness & USA & $\begin{array}{l}\text { CS1: } 34 \\
\text { CS2: } 36\end{array}$ & Clickers \\
\hline Bain and Przybyla (2009) & $\begin{array}{l}\text { Performance, Enjoyment, Interest, } \\
\text { Attendance, Participation, Comprehension, } \\
\text { Preparation }\end{array}$ & USA & 32 & Student Respo \\
\hline $\begin{array}{l}\text { Humphries and Whelan } \\
(2009)\end{array}$ & Effectiveness, Learning & USA & 113 & Personal Resp \\
\hline Lojo (2009) & Effectiveness, Performance & USA & 508 & Clickers \\
\hline Mula and Kavanagh (2009) & $\begin{array}{l}\text { Efficacy, Engagement, Feedback, } \\
\text { Performance }\end{array}$ & Australia & $\begin{array}{l}\text { CS1: } 33 \\
\text { CS2: } 61 \\
\text { CS3: } 26 \\
\end{array}$ & Student Respo \\
\hline Hancock (2010) & Assessment & USA & $\begin{array}{l}\text { CS1: } 216 \\
\text { CS2: } 244\end{array}$ & Audience Res \\
\hline Sprague and Dahl (2010) & $\begin{array}{l}\text { Satisfaction, Teaching Practice, Attitudes, } \\
\text { Learning Experience } \\
\text { Anonymity, Security }\end{array}$ & Canada & 93 & Personal Resp \\
\hline Stagg and Lane (2010) & $\begin{array}{l}\text { Active Learning, Engagement, Instant } \\
\text { Feedback }\end{array}$ & Australia & $\begin{array}{l}\text { CS1: } 107 \\
\text { CS2: } 51\end{array}$ & Student Respo \\
\hline Thoms and Williams (2010) & $\begin{array}{l}\text { Enjoyable, Interactive, Achievement, } \\
\text { Feedback }\end{array}$ & USA & 40 & Student Respo \\
\hline
\end{tabular}




\begin{tabular}{|c|c|c|c|c|}
\hline & Motivation, Active Participants & & & \\
\hline Carnaghan et al. (2011) & $\begin{array}{lll}\begin{array}{l}\text { Satisfaction, } \\
\text { enjoyment }\end{array} & \text { Engagement, } & \text { Learning, } \\
\end{array}$ & USA & 4 Professors & Student Respo \\
\hline Dunnett et al. (2011) & Attendance, Performance & Canada & $\begin{array}{l}\text { CS } 1=18 \\
\text { CS2 }=39 \\
\text { CS3 }=40\end{array}$ & Student Respo \\
\hline Eastman et al. (2011) & Attitude, Satisfaction & USA & 97 & Clickers \\
\hline Jones (2011) & $\begin{array}{l}\text { Attitude, Motivation, } \quad \text { Understanding, } \\
\text { Involvement, Interaction, Participation }\end{array}$ & USA & 106 & Clickers \\
\hline Jones and George (2011) & Attitude & USA & $\begin{array}{c}54 \\
\text { Instructors }\end{array}$ & Clickers \\
\hline Slauson (2011) & Instant Engagement, Interactivity, Interest & USA & 25 & Clickers \\
\hline Buyukkurt et al. (2012) & Attention & Canada & 162 & Classroom Re \\
\hline Keough (2012) & $\begin{array}{l}\text { Actual Performance, } \quad \text { Satisfaction, } \\
\text { Perceived Performance, Attention Span, } \\
\text { Attendance, Participation } \\
\text { Feedback, Ease of use }\end{array}$ & USA & $\begin{array}{l}\text { S1 }=66 \text { Studies } \\
\text { S2 }=94 \text { Students }\end{array}$ & Clickers \\
\hline Kullven and Westin (2012) & $\begin{array}{l}\text { Participation, Controlling, Attendance, } \\
\text { Setting the Grade, Satisfaction, Positive } \\
\text { Attitude } \\
\text { Learning }\end{array}$ & Sweden & 37 & Clickers \\
\hline Marshall and Varnon (2012) & $\begin{array}{l}\text { Performance, Engagement, Motivation, } \\
\text { Attention }\end{array}$ & USA & 91 & Clickers \\
\hline Blasco-Arcas et al. (2013) & Performance, Engagement, Interactivity & Spain & 159 & Clicker Techn \\
\hline Chui et al. (2013) & Confidence, Performance & USA & $\begin{array}{l}\mathrm{CS} 1=38 \\
\mathrm{CS} 2=48\end{array}$ & Student Respo \\
\hline Fryling (2013) & $\begin{array}{l}\text { Participation, Engagement, } \\
\text { Understanding }\end{array}$ & USA & $\begin{array}{l}\mathrm{CS} 1=48 \\
\mathrm{CS} 3=45 \\
\mathrm{CS} 3=40 \\
\mathrm{CS} 4=38\end{array}$ & Clickers \\
\hline Han and Finkelstein (2013) & $\begin{array}{l}\text { Assessment, Feedback, Engagement, } \\
\text { Learning }\end{array}$ & Canada & $\begin{array}{c}\mathrm{S} 1=74 \\
\mathrm{~S} 2=5459\end{array}$ & Clickers \\
\hline Hoanca (2013) & Performance & USA & $\begin{array}{l}\mathrm{CS} 1=21 \\
\mathrm{CS} 2=16 \\
\mathrm{CS} 3=20 \\
\mathrm{CS} 4=23\end{array}$ & Clickers \\
\hline Heaslip et al. (2014) & $\begin{array}{l}\text { Engagement, Participation, Anonymity, } \\
\text { Ease of Use }\end{array}$ & Ireland & 120 & Student Respc \\
\hline
\end{tabular}




\begin{tabular}{|l|l|l|l|l|}
\hline $\begin{array}{l}\text { Hedgcock and Rouwenhorst } \\
(2014)\end{array}$ & $\begin{array}{l}\text { Feedback, Learning, Performance, } \\
\text { Attitude, Understanding }\end{array}$ & USA & $\begin{array}{l}\text { CS1 }=37 \\
\text { CS2 }=38 \\
\text { CS3 }=35 \\
\text { CS4 }=34\end{array}$ & Student Respo \\
\hline
\end{tabular}

